\title{
Erratum to: General procedure for determining cellulose nanocrystal sulfate half-ester content by conductometric titration
}

Stephanie Beck • Myriam Méthot •

Jean Bouchard

Published online: 1 January 2015

(C) Springer Science+Business Media Dordrecht 2014

\section{Erratum to: Cellulose \\ DOI 10.1007/s10570-014-0513-y}

In the original publication, the cellulose nanocrystal (CNC) sample provided by Alan Rudie of the US
Forest Products Laboratory was incorrectly stated to have been produced from southern softwood sulfite pulp.

The CNC sample was in fact produced from prehydrolysis softwood kraft dissolving pulp.
The online version of the original article can be found under doi:10.1007/s10570-014-0513-y.

S. Beck $(\square) \cdot$ M. Méthot · J. Bouchard Pulp, Paper and Biomaterials Division, FPInnovations, 570 Boulevard St-Jean, Pointe-Claire, QC H9R 3J9, Canada

e-mail: stephanie.beck@fpinnovations.ca 